\title{
Konvensi-Konvensi dalam Drama dan Teater Rendra
}

\author{
Nur Sahid ${ }^{1}$ \\ Jurusan Teater, Fakultas Seni Pertunjukan, Institut Seni Indonesia Yogyakarta
}

\begin{abstract}
ABSTRAK
Tujuan penelitian ini adalah untuk mengungkapkan kekhasan proses kreatif Rendra dalam penciptaan karya teater dan drama-dramanya. Konvensi karya drama dan teater Rendra menarik untuk dikaji, sebab Rendra adalah tokoh pembaharu teater modern terkemuka, baik itu dalam bidang penulisan drama, penyutradaraan maupun keaktoran. Kehadirannya dalam khazanah teater Indonesia sangat berpengaruh, sehingga melahirkan sejumlah pengikut dalam penciptaan teater.

Kata Kunci: Rendra, konvensi teater, penyutradaraan, drama sosial
\end{abstract}

\section{ABSTRACT}

The Conventions on Rendra's Theatre and Drama. The research on the convention analysis of Rendra's theatrical works and dramas is aimed to reveal the special characteristic of Rendra's creative process especially on the creation of his theatrical works and dramas. The convention of Rendra's theatrical works and dramas is interesting to be analyzed since he was famed as the pioneer of modern theater on the field of play writing, play directing, and acting as well. His existence has strongly influenced to the theatrical works, therefore, there can be found some of the followers in creating the theater activities born in the field of theater in Indonesia.

Keywords: Rendra, the convention of theater, directing, social critisism

\section{Pendahuluan}

Hari kamis Tgl 6 Agustus 2009 penyair, teaterawan, budayawan dan pejuang demokrasi kenamaan Rendra berpulang ke Rakhmatullah. Rendra meninggal hanya berselang dua hari dengan Mbah Surip sahabatnya. Kematian Mbah Surip yang dimakamkan di kompleks pemakaman keluarga Rendra seolah-olah justru seperti ingin menjemput Rendra untuk pergi ke alam yang sama, yakni akherat. Terbukti secara kebetulan Rendra pun 'mengikuti' kepergian Mbah Surip di alam baqa. Kepergian seniman kharismatik ini Rendra bukan saja meninggalkan kesan yang mendalam bagi publik kesenian di tanah air. Lebih dari itu, kita kehilangan sosok seniman, intelektual, dan budayawan yang sulit tergantikan. Hal ini karena kepeloporan Rendra dalam bidang kepenyairan, teater, dan pemikir demokrasi sulit ditandingi oleh siapapun.

Oleh karena itu, untuk mengenang jasa-jasa Rendra yang juga pernah mendapatkan gelar Doctor Honoris Causa dari UGM 2008 tersebut ada baiknya kita membuka kembali prestasiprestasi kultural yang pernah dihasilkannya, khususnya dalam bidang teater. Hal ini didasarkan pada pertimbangan bahwa selama ini di antara karya seni Rendra yang lebih banyak dikaji para peneliti adalah karya jenis puisi. Sementara itu, karya teater yang berjenis konvensional jarang dikaji secara komperehensif. Padahal melalui karya teater dan dramanya Rendra merupakan peletak dasar penulisan drama dengan estetika protes sosial (kritik sosial) di Indonesia. Demikian intensifnya kritik sosial yang disuarakan Rendra, sehingga pertunjukannya pada tahun 70 -an yang selalu sering dilarang aparat keamanan. Rendra pun pernah mendekam di penjara selama 6 bulan akibat keberaniannya mengritik rezim Orde Baru yang otoriter dan korup.

Seperti diketahui bahwa setelah akhir tahun 60-an Rendra intensif melahirkan teater mini kata, maka mulai awal tahun 70-an Rendra kembali ke teater konvensional dengan basis drama-drama yang bercerita. Hal ini tampak dalam Mastodon dan Burung Kondor (1973), Kisah Perjungan Suku Naga (1975), Sekda (1977), Panembahan Reso (1988) dll.

Selain menulis drama asli, Rendra juga banyak menerjemahkan dan mengadaptasi dramadrama Barat untuk kepentingan pementasan Bengkel Teater seperti karya Sophocles, William Shakespeare dsb.

1 Alamat Korespondensi: Prodi Teater ISI Yogyakarta. Jalan Parangtritis KM. 6,5 Sewon, Yogyakarta 55001. E-mail: nur.isijogja@yahoo.co.id. 
Salah satu ciri khas dari drama-drama Rendra adalah secara intensif mengangkat masalahmasalah sosial yang terkait sistem politik Orde Baru yang korup, otoriter, dan tidak berkeadilan sosial. Dalam realitas sosial politik Indonesia mutakhir, masalah-masalah tersebut senantiasa diperjuangkan oleh para pejuang demokrasi dan dan keadilan sosial di Indonesia, tidak terkecuali Rendra. Karena itu, sekalipun drama-drama itu telah ditulis beberapa puluh tahun yang lalu, namun gagasan yang diungkapkan Rendra tetap aktual sampai sekarang. Inilah yang menjadi salah satu tujuan diadakannya analisis terhadap konvensi-konvensi karya teater dan drama-drama Rendra kali ini.

Pada dasarnya setiap seniman dalam menciptakan karya seni memiliki konvensi tersendiri dalam penciptaan karya seni yang berbeda dengan karya seniman lain. Panuti Sudjiman (1985: 43) mengatakan bahwa konvensi merupakan penyajian yang menjadi alat pengungkapan yang mapan, yang akhirnya menjadi teknik yang diterima umum. Sementara itu, Abrams (1981: 33) mengatakan bahwa konvensi merupakan ciri-ciri yang menonjol atau teknik-teknik yang berulang dalam karya sastra seperti jenis -jenis penokohan, alur, bentuk-bentuk syair, diksi, dan gaya bahasa. Berdasarkan dua pendapat tersebut dapat dirumuskan bahwa konvensi merupakan ciri-ciri dominan dan berulang-ulang muncul dalam karya sastra yang berupa jenis penokohan, alur, bentuk-bentuk syair, diksi, gaya bahasa dsb.

Sekalipun teori konvensi tersebut mengacu pada karya sastra, tetapi sebagian di antaranya juga dapat diberlakukan pada karya seni yang lain seperti teater dan drama. Misalnya, hal-hal yang terkait dengan ciri-ciri yang dominan, penokohan, dsb. Apalagi drama memang termasuk genre karya sastra. Konvensi yang menjadi kekhasan karya seni seseorang biasanya disesuaikan dengan estetika yang menjadi pilihan seorang seniman. Apabila ciri-ciri estetika penciptaan itu secara dominan sering berulang dalam penciptaan karya seni seseorang, maka hal itu akan menjadi konvensi penciptaan seniman yang bersangkutan.

Dalam konteks ini, istilah teater mengacu kepada pertunjukan teater yang di dalamnya terhimpun berbagai elemen teater seperti naskah drama, aktor, dan unsur-unsur pemanggungan lainnya seperti tata tekenik pentas, tata cahaya, tata busana, tata musik, tata rias dsb. Sementara itu, istilah drama mengacu kepada naskah yang menjadi dasar produksi pementasan teater. Istilah lain dari drama adalah play, repertoir, dan lakon. Beberapa pakar yang membuat perbedaan antara istilah drama dengan teater antara lain adalah Jassin (1985), Keir Elam (1991), Elain Aston \& George Savona (1991), Wellek \& Warren (1989).

Tujuan utama terhadap analisis konvensikonvensi karya teater dan drama-drama Rendra ini adalah untuk mengungkapkan kekhasan proses kreatif Rendra tertama dalam penciptaan karya teater dan drama-dramanya. Konvensi karya drama dan teater Rendra menarik untuk dikaji. Hal ini berdasarkan pertimbangan bahwa Rendra sebagai tokoh teater modern terkemuka adalah sosok pembaharu, baik itu dalam bidang penulisan drama, penyutradaraan maupun keaktoran. Kehadirannya dalam khazanah teater Indonesia pun cukup berpengaruh, sehingga melahirkan sejumlah pengikut dalam penciptaan teater.

Pada pihak lain, hingga sekarang belum ada kajian yang secara khusus mencari konvensi dramawan tertentu, termasuk Rendra. Padahal penelitian semacam itu memiliki arti penting bagi upaya memahami kekhasan berkesenian seseorang. Sampai sekarang, belum pernah ada peneliti lain yang mengkaji konvensi-konvensi karya teater dan drama drama dari Rendra. Penelitian yang bertopik konvensi kepengarangan itu sendiri termasuk topik yang jarang dikaji orang. Hingga sekarang baru Faruk (1987) yang pernah menulis konvensi kepengarangan seseorang, yakni konvensi kepengarangan Putu Wijaya dalam menulis cerpen.

Sebenarnya tidak ada konvensi (seni) teater yang berlaku pada pada semua orang atau semua kelompok teater. Hal ini karena setiap teaterawan dan group teater memiliki konvensi sendiri-sendiri. Tinjauan tentang konvensi teater Rendra akan mencakup beberapa segi atau elemen teater sebagai sesuatu yang mendukung keutuhan sistem konvensi itu sendiri. Berbagai fakta yang ada menunjukkan bahwa di antara pementasan karya-karyanya terdapat beberapa hal yang berulang yang dapat dijadikan suatu petunjuk ke arah konvensi proses berteater Rendra. Dalam hal ini, konvensi karya teater Rendra yang akan dibahas mencakup karya teater Rendra sebagai 
teater sutradara, Rendra sebagai pemeran utama, fungsi sosial teater, dan Rendra sebagai penulis naskah. Sementara itu, untuk konvensi dramadrama Rendra difokuskan pada tema, penokohan, dan latar. Secara selintas pola-pola berulang yang menjadi konvensi itu akan dipaparkan berikut ini.

\section{Konvensi Berteater Rendra}

Elemen-elemen dari sebuah pertunjukan teater melibatkan perangkat yang yang cukup banyak seperti sutradara, aktor, unsur-unsur pementasan yang lain seperti tata pentas, tata cahaya, tata rias, tata busana, tata musik dsb. Tentu saja dalam analisis ini tidak semua unsur yang mendukung sebuah konvensi pertunjukan dibahas, namun hanya beberapa unsur pertunjukan yang memang selalu berulang dalam pementasan karya Teater Rendra yan akan dibahas. Konvensi-konvensi karya teater Rendra tersebut adalah konsep penyutradaraan, pemeranan, dan fungsi sosial pertunjukan teater, penulisan naskah drama. Dipilihnya keempat unsur pementasan tersebut didasarkan pada alasan bahwa keempat unsur tersebut cukup dominan perannya dalam setiap pementasan karya teater Rendra di Bengkel Teater.

\section{Penyutradaraan}

Dalam tradisi teater Barat abad ke-20, tanggung jawab atas pengorganisasian sistem tanda dalam teater adalah seorang sutradara. Pada satu sisi dramawan adalah penulis naskah drama, sedangkan sutradara memegang kontrol atas bentuk teater dengan tugas mengorganisasi sistem-sistem penandaan teater (lighting, dekor, properti dll) ke dalam suatu proses termodifikasi yang selaras dengan produksi teater (Aston \& Savona, 1991 : 100). Jika sutradara gagal dalam tugas ini, maka pertunjukan itu sendiri tidak akan dipahami oleh penonton.

Penyutradaraan memiliki peran penting, sebab penyutradaraan berkaitan dengan kerja sejak perencanaan pementasan hingga pementasan berakhir. Tugas sutradara selain melatih para pemeran, juga memimpin urusan pentas seperti lighting, dekor, properti, penata musik, penata rias, penata busana dll (Nur Sahid, 2004: 73). Setidaknya terdapat 2 model pendekatan penyutradaraan teater, yakni model Gordon Craig dan Laisses Faire (Harrymawan, 1993: 64-65). Penyutradaraan model Gordon Craig mengharuskan kerja penyutradaraan selalu tertib, teratur, teliti, dan sempurna. Kelemahan jenis penyutradaraan demikian adalah munculnya kediktatoran sutradara, sebab aktor dan aktris hanya menjadi alat sutradara. Para pemeran harus meniru gaya sutradara, sehingga kreativitas para pemeran tidak muncul secara maksimal. Pementasan yang menggunakan model pendekatan penyutradaraan demikian biasa disebut dengan "teater sutradara". Sebaliknya, penyutradaraan model Laisses Faire lebih memberi kesempatan kepada para pemeran sebagai pencipta pertunjukan. Tugas sutradara adalah membantu para pemeran mengekspresikan kreativitas mereka dalam pertunjukan, sehingga mereka dapat berkembang sesuai bakat dan kemampuannya.

Rendra adalah dramawan yang cukup produktif. Selain menerjemahkan dan mengadaptasi sejumlah drama dunia seperti Oedipus Berpulang, Hamlet, Menunggu Godot, Lysistrata, Perampok, Buku Harian Seorang Penipu dll., ia juga menulis drama Orang-Orang di Tikungan Jalan, Mastodon dan Burung Kondor, Kisah Perjuangan Suku Naga, Sekda, Panembahan Reso dll. Drama karya asli, hasil terjemahan, maupun adaptasi biasanya pernah dipentaskan Bengkel Teater

Sampai dengan akhir 60-an, seorang penulis naskah drama jarang terintegrasi dengan group teater. Pada saat itu sebuah group teater kebanyakan mementaskan karya-karya orang lain termasuk karya terjemahan dari Barat. Sejak Rendra berkiprah dengan Bengkel Teater, ia mulai menulis naskah untuk kepentingan pentas sendiri, di samping juga mementaskan karya orang lain. Kalau dilihat dari segi penyutradaraan, pementasan Bengkel Teater cenderung menggunakan pendekatan "teater sutradara". Maksudnya, dominasi sutradara dalam mengarahkan teknik peran kepada para aktornya cukup kuat. Para aktor cenderung hanya sebagai media pengekspresian ide sang sutradara. Sutradara seperti menjadi diktator sebab aktor dan aktris hanya meniru pola kreasi sutradara.

Akibatnya kreativitas aktor secara individu kurang berkembang sebab para aktor dan aktris seolah-olah hanya menjadi alat sutradara. Para aktor bengkel teater kurang dikenal publik dibandingkan Rendra sebagai sutradara. Setelah para aktor dan aktris Bengkel Teater keluar dari 
Bengkel, mereka baru dikenal masyarakat luas seperti Chairul Umam, Amak Baljun, Putu Wijaya dll.

Berbagai fakta di atas itulah yang mengantar Rendra dan karya teaternya sering mendapat julukan sebagai teater sutradara. Kenyataannya pola teater sutradara ini akhirnya justru diikuti beberapa teaterawan lain seperti Arifien C. Noer di Teater Kecil, Putu Wijaya di Teater Mandiri, Ikranegara di Teater Saja, dsb. Jelaslah bahwa bidang penyutradaraan Rendra ternyata juga cukup berpengaruh bagi teaterawan lain.

\section{Sering Menjadi Pemeran Utama}

Berperan dalam sebuah pertunjukan teater berarti menjadi orang lain sesuai dengan tuntutan lakon drama. Ketrampilan seorang aktor dalam berperan ditentukkan oleh kemampuannya meninggalkan egonya untuk memasukkan dan mengekspresikan tokoh lain yang dibawakan (Waluyo, 2007: 114). Dalam sebagian besar pementasan Bengkel Teater, Rendra sering memerankan tokoh utama. Misalnya, dalam drama Oedipus Berpulang Rendra berperan sebagai Oedipus, dalam Hamlet sebagai Hamlet, dalam Perampok sebagai R Sudrajat, dalam Mastodon dan BurungKondor sebagai penyair Jose Karosta, dalamSekda sebagai Sekda, dalam Panembahan Reso sebagai Panji Reso, dalam Selamatan Cucu Sulaiman sebagai Suto. Hanya sedikit pementasan Bengkel Rendra sebagai pemeran utama. a, dalam pementasan Buku Harian Seorang Penipu Rendra memerankan Dyah Retno Suminar sebagai pemeran bawahan.

Tidak berlebihan kalau Goenawan Mohamad (1981) ketika mengulas pementasan Hamlet oleh Bengkel Teater mengatakan bahwa masa depan teater Indonesia akan mengalami krisis keaktoran akibat kecenderungan teater Indonesia (saat itu) yang tidak memberi tempat perkembangan seni peran. Sinyalemen Goenawan Mohamad itu setidaknya berlaku untuk Bengkel Teater. Salah satu bukti di Bengkel Teater tidak ada regenerasi aktor secara signifikan tampak dari pementasan Hamlet di TIM 26 Januari-4 Februari 1994. Drama Hamlet telah dipentaskan Bengkel Teater sebanyak tiga kali, yakni tahun 1971, 1976, dan 1994. Dalam ketiga pementasan itu Rendra selalu memerankan Hamlet yang merupakan tokoh sentralnya.
Fakta demikian mengisyaratkan seolah-olah tidak ada aktor lain selain Rendra yang dianggap mampu memerankan tokoh tsb. Rendra yang saat itu berumur 58 tahun tampak kepayahan memerankan Hamlet yang berumur 20-an tahun. Begitu pula pementasan Oedipus Bengkel Teater bulan Juli 1987 di Balai Sidang Senayan yang juga merupakan penampilan Rendra yang ketiga sebagai pemeran Oedipus (pertama di Yogyakarta 1964, dan kedua di TIM 1969 bersama Bengkel Teater).

\section{Cenderung Mementingkan Fungsi Sosial}

Fungsi teater bagi kehidupan sosial tidak hanya menjadi milik teater tradisional, melainkan juga teater modern. Berkaitan dengan fungsi teater, George Gurvitch (Burns, 1973: 79) mengatakan bahwa fungsi sosial teater bisa bermacam-macam, yakni bagi masyarakat tradisional teater berkaitan dengan fungsi ritual, pada masyarakat rezim klasik (ancient rezim) teater berfungsi untuk justifikasi rasional dan pendidikan intelektual bagi masyarakat, pada masyarakat liberal kapitalis teater berfungsi untuk menghibur masyarakat, pada negara-negara Eropa Timur saat komunis berjaya teater berfungsi untuk perjuangan kaum tertindas. Apabila dicermati beberapa fungsi sosial teater itu di manakah posisi teater Rendra? Kalau disimak kecenderungan karya Rendra, terutama untuk drama-drama asli dan yang berjenis konvensional, cenderung berfungsi sebagai justifikasi rasional dan pendidikan intelektual.

Rendra pernah mengatakan bahwa sebagai seniman dirinya menganut ideologi sosial sehingga karya-karyanya senantiasa terlibat pada nilai-nilai yang lebih makro yang berkaitan kehidupan sosial tanpa harus kehilangan "kebebasan kreatif" dan "kebebasan individu" (1983:75). Karenanya karyakarya Rendra baik sajak-sajaknya maupun karya teaternya selalu mengangkat masalah-masalah yang bersumber pada ketimpangan sosial politik di Indonesia. Sesungguhnnya, bukan sesuatu yang salah apabila seseorang dalam berkarya seni lebih mementingkan relevansinya bagi kehidupan, sebab ia menempatkan dirinya sebagai pemberi kesaksian dan penghayatan terhadap kenyataan yang mengungkungnya (Nur Sahid, 2008: 99). Pada sisi lain, Rendra menyebutkan bahwa adat 
istiadat, keadaan sosial, politik, dan ekonomi lahir dari pikiran manusia sehingga ia bisa diubah (1983: 72). Kenyataan sosial dan kenyataan kebudayaan tidak layak diberhalakan, melainkan harus bisa diubah kalau memang secara analitis dan objektif telah mengganggu kehidupan.

Bertolak dari wacana pemikiran Rendra tsb. dapat diambil kejelasan bahwa melalui karya teaternya secara langsung ataupun tidak langsung sebenarnya Rendra menyampaikan pendidikan intelektual kepada audiens tentang hak-hak sosial, politik, ekonomi, dan kebudayaan mereka. Harus diakui, karya teater Rendra menunjukkan kekayaan ide dan pemikirannya tentang berbagai hal. Hanya saja akibat begitu intensnya ingin "mendidik" audiens, maka tidak bisa dipungkiri bahwa karya-karyanya sering terjebak pada dialogdialog yang mirip dengan pidato-pidato politik. Ini terjadi karena karya teater Rendra adalah manifestasi dari reaksi terhadap kebobrokan sosial politik pada era Orde Baru.

Dengan demikian, karya kreatif Rendra itu lebih merupakan kreasi reaktif, daripada kreasi yang kreatif. Kreasi yang reaktif cenderung menjadikan karya teater sekedar sebagai reaksi kreatornya atas berbagai masalah yang terjadi di sekelilingnya. Kreasi reaktif membuat penonton menjadi pasif dan puas dengan sikap pasifnya. Ia juga tidak bisa mendinamisir jiwa dan pikiran penonton untuk secara aktif memahami keunikankeunikan masalah yang ada di balik fenomena sosial yang dipanggungkannya.

Demikianlah konvensi fungsi sosial dari karya teater Rendra. Yang jelas tontonan Rendra tidak sekedar sebagai ekspresi artistiknya, tetapi juga media pendidikan intelektual bagi publik.

\section{Penulis, Penerjemah dan Pengadaptasi Naskah}

Selain ketiga konvensi di atas, maka masih tedapat sebuah kecenderungan yang menjadi pola proses kreatif Rendra. Konvensi tersebut adalah posisi Rendra yang selalu menjadi penulis, penerjemah dan pengadaptasi naskah drama yang dipentaskan Bengkel Teater. Drama-drama dunia yang pernah diterjemahkan sekaligus dipentaskan Bengkel Teater antara lain Oedipus Berpulang, Hamlet, Menunggu Godot, Lysistrata,dll. Naskah hasil adaptasi Rendra antara lain berjudul Perampok, Buku Harian Seorang Penipu dll. Sementara itu, untuk naskah asli Rendra antara lain menulis drama Orang-Orang di Tikungan Jalan, Mastodon dan Burung Kondor, Kisah Perjuangan Suku Naga, Sekda, Panembahan Reso dll.

Sampai tahun 2009 ini, hampir semua pementasan Bengkel Teater selalu melibatkan Rendra sebagai penulis, penerjemah atau pun pengadaptasi naskah. Hanya ada satu pentas yang tidak melibatkan Rendra sebagai penulis naskah drama, yakni pada pementasan Sobrat . Drama Sobrat adalah karya Arthur S. Nalan yang berhasil memenangkan sayembara penulisan naskah drama Dewan Kesenian Jakarta 2005. Drama tersebut dipentaskan di Graha Bakti Budaya TIM tgl. 2326 Juni 2005.

$\mathrm{Hal}$ ini menunjukkan betapa kuatnya posisi Rendra dalam banyak bidang di group tersebut. Oleh karena segala hal yang berkaitan dengan naskah selalu ditangani Rendra, maka tidak ada regenerasi penulisan naskah di Bengkel Teater. Dengan demikian, seandainya Rendra sudah tidak aktif maka akan terjadi kevakuman kreator dalam penulisan naskah. Hal ini jelas sangat membahayakan masa depan Bengkel Teater.

\section{Konvensi Drama-Drama Rendra}

Tinjauan konvensi drama atau lakon-lakon Rendra terutama difokuskan pada drama-drama aslinya, bukan saduran dan terjemahan. Hal ini berdasarkan pertimbangan dalam karya-karya terjemahan dan saduran jarang bisa ditemukan pengucapan dan pribadi yang khas dari seorang pengarang, kecuali dalam karya aslinya. Hal ini bukan berarti bahwa pada karya sadurannya tidak diketemukan kekhasan pengucapan Rendra, misalnya Perampok, sehingga tidak mengesankan sebagai karya saduran. Dalam hal ini, di antara karya drama Rendra yang asli yang dipilih judul untuk mewakili analisis konvensi ini adalah Mastodon dan Burung Kondor (MBK), Kisah Perjuangan Suku Naga (KPSN), dan Panembahan Reso (PR). Ketiga karya tersebut dianggap bisa mewakili karya asli Rendra. Dalam membahas konvesi drama Rendra kajian akan difokuskan pada struktur tema, penokohan dan latar cerita.

\section{Tema}

Tema adalah suatu unsur pembentuk cerita seperti cerpen, novel, film, drama dan karya naratif lainnya. Tema dalam suatu roman atau drama merupakan patokan untuk membangun cerita. 
Pengarang akan selalu memadukan tema bersama dengan fakta-fakta cerita dan alat-alat penceritaan sehingga tersusunlah sebuah cerita. Mochtar Lubis dalam Tehnik Mengarang menganggap tema sebagai dasar cerita (1981: 14 ). Menurut Stanton (1965: 4 ) tema yang disebutnya sebagai ide cerita merupakan sebuah arti pusat yang terdapat dalam cerita. Tema memberikan kekuatan dan kesatuan kepada peristiwa-peristiwa yang di terangkan dan menceritakan sesuatu kepada seseorang tentang kehidupan pada umumnya. Tema dalam suatu lakon tidak selalu disampaikan secara langsung oleh pengarang. Pada umumnya tema disampaikan secara implisit, pengarang memasukkan tema itu secara bersama-sama dengan kenyataan-kenyataan dan kejadian-kejadian dalam cerita. Dengan demikian, tema merupakan suatu unsur yang berfungsi sebagal pemersatu elemen elemen cerita yang lain.

Sebagian besar drama-drama Rendra mengangkat masalah-masalah yang bersumber pada penyimpangan tatanan sosial, ekonomi, politik, dan kebudayaan yang dilakukan rezim Orde Baru. Rendra menjadikan karyanya sebagai usaha untuk menanggapi atau mengritik penyimpangan tsb. Dalam drama-drama Rendra, penyimpangan sebuah tatanan mengakibatkan tokoh-tokoh memasuki sebuah dunia yang terdegradasi.

Drama MBK mengangkat masalah tentang tokoh-tokoh yang hidup di tengah-tengah masyarakat yang sedang bergolak menentang rezim diktator di salah satu negara Amerika Latin. Gerakan revolusi yang dilakukan Prof. Topas, Juan Frederico, Fabiola, Mayor Ramos, Kol. Santos dkk. untuk menumbangkan kekuasaan Max Carlos yang cenderung diktator, korup, dan mendewa-dewakan pembangunan fisik. Sebagai penyair, Jose Karosta bisa mengambil jarak antara dua kelompok yang saling bertikai sebab ia tidak setuju dengan rezim penguasa maupun kaum revolusioner. Dunia yang dihadapi Karosta adalah dunia yang sedang memburuk (terdegradasi) tatanan sosial dan politiknya.

KPSN mengangkat masalah tentang perjuangan Abivara menentang pola pembangunan rezim Kerajaan Astinam yang kapitalistik, sehingga mengenyampingkan pelestarian ekologi dan nilai-nilai kultural masyarakat Suku Naga. Abivara menjadi saksi terhadap memburuknya kondisi sosial politik Kerajaan Astinam akibat para pengausa (Ratu Astinam, Parlemen, Menteri, Keamanan dkk.) termakan demam modernisasi, dan kapitalisme internasional yang digerakkan Mr. Joe, The Big Bos dll. Berkat bantuan wartawan asing Carlos akhirnya Abivara memenangkan perjuangan masyarakat Suku Naga. Masyarakat Suku Naga tidak jadi digusur, sebab Ratu Astinam takut dengan sanksi lembaga-lembaga internasional yang telah memberi bantuan pembangunan.

PR mengangkat masalah tentang kondisi sosial politik yang tidak menentu akibat terjadinya perebutan kekuasaan di lingkungan elit kerajaan Raja Tua. Pada satu sisi Ratu Dara dan anak-anak Raja Tua saling berebut pengaruh untuk mendongkel tahta Raja Tua yang dianggap otoriter dan kurang aspiratif. Pada pihak lain, di balik usaha Panji Reso mendukung cita-cita Ratu Dara yang akan merajakan Pangeran Rebo sebenarnya tersimpan ambisi pribadi untuk memburu tahta bagi dirinya sendiri. Panji Tumbal tidak memihak kepada mereka. Tumbal yang menjadi saksi terdegradasinya situasi sosial politik kerjaan itu berjuang menuntut pemerataan keadilan (demokratisasi) dalam berbagai bidang kehidupan.

Ketiga drama di atas merupakan manifestasi kritik Rendra terhadap tatanan sosial, ekonomi, politik, dan kebudayaan rezim Orde Baru. Pola pembangunan yang lebih mengutamakan pertumbuhan ekonomi ternyata telah berdampak terhadap berkembangnya korupsi, aspirasi politik yang tersumbat, sentralisasi kekuasaan, dan kehidupan kebudayaan yang compang-camping. Akibatnya muncullah, Jose Karosta, Abivara, dan Panji Tumbal yang menyuarakan aspirasi arus bawah untuk menuntut pemerataan keadilan dan kehidupan politik yang lebih demokratis (MBK dan PR), dan pembangunan yang berimbang antara fisik dengan pelestarian alam dan nilainlai budaya asli (KPSN). Tokoh-tokoh yang menghadapi dunia yang terdegradasi umumnya adalah tokoh protagonis (Jose Karosta dan Abivara), kecuali Panji Tumbal yang merupakan antagonis.

Demikianlah, konvensi tema dalam dramadrama Rendra. Dalam mencari tema untuk drama-dramanya, Rendra senantiasa mengangkat masalah-masalah aktual yang terjadi dalam masyarakatnya, sehingga tema-tema tersebut 
sering disebut sebagai tema protes sosial (kritik sosial). Tema protes sosial ini membingkai struktur cerita yang lain, sehingga pemahaman setiap unsur yang ada harus dikembalikan kepada temanya.

\section{Penokohan}

Unsur penokohan merupakan faktor penting dalam pencipta cerita. Begitu urgennya fungsi tokoh dalam cerita sehingga tak pernah ada satu cerita pun yang tidak melibatkan kehadiran seorang pemeran. Perbuatan atau perilaku-tokoh pada hakekatnya dapat memperlihatkan watak atau sifatnya. Saleh Saad mengatakan (1967: 123) bahwa watak atau sifat tertentu dapat memberikan alasan mengapa si tokoh dapat berbuat sesuatu atau tidak berbuat sesuatu. Dalam drama tiaptiap perbuatan tidak boleh menyimpang dari sifat dasar yang dimiliki pelaku cerita. Dengan demikian, perbuatan-perbuatan tersebut harus berkembang sesuai dengan perkembangan jiwa pelakunya (Pradopo, 1976: 31 ).

Tokoh-tokoh dalam drama terdiri atas seorang atau beberapa orang pelaku. Pada lakon yang pelakunya lebih dari satu pasti ada yang menduduki tokoh utama atau sentral atau prota gonia, tokoh antagonis atau tokoh kedua dan tokoh komplementer atau tokoh pelengkap (Pradopo 1976: 31). Rene Weliek dan Austin Warren (1989: 288) menyebut ada dua tipe watak dalam novel mapun drama, yaitu flat characterization (watak datar atau statis) dan round characterization (watak bulat atau dinamis). Penokohan datar menampilkan satu kecenderungan yang dianggap dominan atau kecenderungan yang paling jelas secara sosial. Forster (Abrams, 1981: 21) menganggap watak bulat sebagai jenis watak yang kompleks dan sulit dijelas kan secara khusus sehingga sulit dideskripsikan secara lengkap seperti manusia dalam kehidupan nyata, ia mampu memberikan semacam kejutan bagi orang yang mengamatinya.

Keberadaan tokoh dalam drama-drama Rendra memegang peranan sangat penting. Tokoh-tokoh dalam ketiga drama Rendra di atas menunjukan garis-garis watak yang tegas, bahkan cenderung hitam putih. Misalnya, tokoh Jose Karosta dan Gloria (MBK), tokoh Abivara, Abisavam, Carlos, Setyawati dalam (KPSN), dan tokoh Panji Tumbal, Kembar, Gada, Dodot, Ratu Padmi, dan Ratu Kenari (PR) cenderung berwatak baik (putih).
Sebaliknya, tokoh Topas, Juan Federico, Max Carlos, Ramos, Santos, Fabiola (MBK), Ratu Astinam, Parlemen, Mr. Joe, The Big Bos (KPSN), tokoh Raja Tua, Ratu Dara, Panji Reso, Bindi, Rebo (PR) termasuk tokoh-tokoh berwatak buruk. Oleh karena perwatakan tokoh-tokoh ketiga drama cenderung hitam putih, karakter masing-masing tokoh nyaris tidak berkembang dan semua berwatak datar.

Dalam melakukan penokohan tokoh-tokohnya, secara tidak langsung Rendra tampak memperkuat teori mimesis mengenai sastra. Maksudnya, tokoh-tokoh tsb. secara mimesis bisa menunjuk manusia di luar karya itu, sebab mereka adalah manusia-manusia yang berkepribadian tertentu. Tokoh-tokoh dalam drama-drama Rendra, khususnya Abivara, Jose Karosta, dan Panji Tumbal, merupakan manusia-manusia yang oleh Lucien Goldmann (1981:11) disebut berada dalam situasi dunia terdegradasi, sehingga mereka berusaha mencari nilai-nilai yang otentik untuk memperbaiki dunia yang tergradasi itu. Dunia yang terdegradasi adalah dunia yang manusiamanusianya menghadapi kondisi moral, sosial, kultural, politik yang memburuk.

Sementara itu, nilai otentik yang dimaksud Goldmann merupakan nilai-nilai yang implisit yang muncul dalam teks yang sekaligus mengorganisasi dengan dunia sebagai totalitas (1981: 1). Nilai-nilai otentik mengandaikan hubungan langsung antara manusia dengan sesamanya, manusia dengan alam, subjek dengan objek hasil kerjanya (Faruk, 1994: 81).

Tokoh Jose Karosta menemukan nilai-nilai otentik berupa langkah memberi jalan ke arah saling pengertian, pemaafan, dan keserasian bagi kehidupan sosial politik antara kelompok yang saling bertikai di negeri itu. Abivara mendapatkan nilai otentik berupa kemenangan perjuangannya menghadapi Ratu Astinam sehingga masyarakat Suku Naga tidak jadi digusur. Panji Tumbal mendapatkan nilai-nilai otentik berupa langkah pemberontakan terhadap Raja Tua dan Bindi untuk menuntut pemerataan keadilan bagi rakyat yang mengalami penurunan kualitas kehidupan sosial politik.

Tokoh Karosta, Abivara, dan Panji Tumbal dapat dikatakan sebagai pencari nilai-nilai otentik di tengah-tengah dunia yang mengalami degradasi nilai-nilai sosial, ekonomi, politik, dan 
budaya. Nilai-nilai itu secara implisit muncul dalam perjuangan Karosta untuk membentuk pemerintahan yang demokratis tanpa harus melalui revolusi, perjuangan Abivara untuk menciptakan modernisasi secara berimbang antara fisik dengan ekologi dan pelestarian kebudayaaan tradisional, dan perjuangan Panji Tumbal untuk menciptakan pemerintahan yang berkeadilan sosial. Menurut istilah Goldmann (1981: 1-2), nilai-nilai yang diperjuangkan Karosta, Abivara, dan Tumbal itulah yang secara implisit mengorganisasi cerita sesuai dengan model dunia sebagai totalitas. Nilai-nilai otentik yang diperjungkan ketiga tokoh secara implisit menjiwai ketiga drama tsb.

Secara simbolis, Karosta, Abivara, dan Tumbal dapat ditafsirkan sebagai penyambung lidah Rendra dalam memperjuangkan demokrasi di Indonesia. Perjuangan ketiga tokoh itu hampir sama dengan perjuangan Rendra menghadapi (dunia) Indonesia yang sedang tergradasi sejak lama.

\section{Latar}

Dapat dipastikan bahwa setiap karya naratif termasuk certa fiksi, film dan drama memiliki elemen latar. Panuti Sudjiman (1988: 44) mengatkan bahwa latar merupakan segala keterangan, petunjuk, pengacuan yang berkaitan dengan waktu, ruang, dan suasana terjadinya cerita, termasuk karya lakon. Semantara itu, M.H. Abrams (1981: 175) membagi latar menjadi tiga bagian yaitu latar tempat, latar waktu, dan latar sosial. Jika dilihat dari batasan di atas, maka yang paling berperan dalam pembentukan watak tokoh dan konflik yang muncul adalah latar sosial.

Latar MBK, KPSN, dan PR adalah dunia yang dihadapi tokoh cerita sehingga membuat tokoh menjadi problematik. Latar tersebut adalah dunia terdegradasi yang mengalami kemerosotan nilai-nilai, sehingga tokoh mengalami konflik dan mencoba memecahkannya dengan mencari nilainilai otentik dalam dunia yang dihadapinya itu.

Sebagai drama-drama konvensional, PR, KPSN dan MBK menunjukkan latar atau dunia yang jelas, baik tentang latar yang bersifat fisik maupun sosial. Secara fisik, latar ketiga drama cukup jelas, baik yang berkaitan dengan tempat kejadian, waktu, maupun benda-benda melingkupi tokoh. Latar sosial ketiga drama mengacu pada kondisi sosial politik yang memburuk akibat penyimpangan kekuasaan yang dilakukan para penguasa. Kondisi sosial politik yang memburuk itu mengakibatkan munculnya revolusi dan intrik politik yang berkepanjangan (MBK). Latar sosial drama ini digambarkan dengan suasana kehidupan sosial politik yang selalu memanas, pertikaian antar kelompok kepentingan, demonstrasi rakyat menentang penguasa Max Carlos dsb.

Latar sosial KPSN ditandai dengan perjuangan masyarakat Suku Naga menentang upaya Ratu Astinam memodernisasi masyarakat Suku Naga dengan mengorbankan ekologi dan nilai-nilai kultural. Latar sosial PR tampak pada kekacauan di seluruh kerajaan akibat pemerintahan yang otoriter dan tidak aspiratif, sehingga memunculkan berbagai pemberontakan dan perebutan kekuasaan sesama elit kerajaan.

Dilihat dari segi latar tempat, tempat kejadian dalam ketiga drama Rendra bersifat fiktif, sebab secara faktual tidak dapat dilacak, kecuali pada MBK. Sekalipun demikian, dilihat dari tema dan permasalahan yang digarap, maka dapat ditafsirkankan bahwa tempat kejadian pada ketiga drama tsb. cenderung simbolik. Tempat kejadian MBK yang menunjuk tempat Amerika Selatan (Amerika Latin), tetapi kritik-kritik yang dilontarkan Rendra mengacu kepada kondisi Indonesia zaman Orde Baru. Tempat kejadian KPNyang menunjuk Kerajaan Astinam sebenarnya hanya simbolisasi dari modernisasi Indonesia yang merusak ekologi dan kebudayaan tradisional. Tempat kejadian PR yang mengacu pada kondisi kerajaan di Jawa masa lalu sesungguhnya dapat ditafsirkan sebagai negara Indonesia juga, sebab sistem kekuasaan yang dikembangkan Raja Tua tidak ada bedanya dengan model kekuasaan rezim Orde Baru.

\section{Penutup}

Berdasarkan analisis terhadap konvenskonvensi pada karya teater dan drama-drama Rendra di atas dapat di ambil kesimpulaan seagai berikut. Pola-pola berulang yang kemudian menjadi konvensi pementasan teater Rendra antara mencakup beberapa hal berikut: pertama, dari sisi penyutradaraan pementasan Bengkel Teater Rendra selalu menggunakan pendekatan teater sutradara terbukti peran sutradara dalam mengarahkan peran kepada para pemeran cukup kuat; kedua, Rendra sebagai sutradara hampir 
selalu berperan sebagai tokoh utama cerita; ketiga, pementasan karya-karya teater Rendra selalu mementingkan fungsi sosial, yakni sebagai media pendidikan intelektual kepada masyarakat khususnya yang menyangkut hak-hak sosial, politik, ekonomi, hukum dan budaya. Itulah yang menjadi konvensi pementasan karya teater Rendra; keempat, sebagiaan besar pementasan Bengkel Teater selalu melibatkan Rendra sebagai penulis naskah, pengadaptasi, dan penerjemah naskah.

Pola-pola yang berulang yang kemudian dapat disebut konvensi drama-drama karya Rendra mencakup beberapa hal berikut. Pertama, dalam pemilihan tema cerita selalu mengangkat masalah kritik sosial terhadap memburuknya kondisi tatanan sosial, politik, ekonomi, hukum dan budaya masyarakatnya (tema protes sosial). Kedua, dalam penokohan Rendra selalu menampilkan tokohtokoh cerita yang hitam putih dan tokoh-tokoh yang membawa amanat pengarang selalu berwatak datar. Ketiga, latar cerita dalam drama-drama selalu menampilkan dunia yang terdegrdasi, yakni sebuah dunia yang mengalami kemerosotan nilainilai sosial, politik, ekonomi, hukum dan budaya.

Rendra di Bengkel Teater menduduki beberapa jabatan sekaligus seperti sutradara, pemeran utama dan penulis naskah. Pada group-group lain jarang ada seseorang yang menduduki posisi yang begitu banyak jabatan sekaligus seperti yang dilakukan Rendra. Di group teater lain seperti Teater Mandiri, Teater Kecil, teater Koma Putu Wijaya Arifien C. Noor, N. Riantiarno sebagai sutradara dan penulis naskah jarang terlibat sebagai pemeran tokoh utama. Melihat begitu sentralnya peran Rendra di Bengkel Teater, maka apabila Rendra sudah meninggal seperti saat ini group itu hanya akan tinggal nama. Bisa demikian karena sumber kreativitas group tersebut hanya bertumpu pada Rendra. Teater Kecil sepeninggal Arifien pun tak ada gemanya. Hampir pasti group-group "teater sutradara" akan menghadapi nasib serupa, kecuali terjadi regenerasi yang berjalan mulus.

\section{Kepustakaan}

Abrams M.H. 1981. A. Glossary of Literary Terms. New York: Holt, Rinehart and Winston.

Aston, Elain \& George Savona. 1991. Theatre As Sign-System: A Semiotics of Text and Performance. London: Rout-ledge.
Elam, Keir. 1991. The Semiotics of Theatre and Drama. London: Rout-Ledge.

Faruk. "Konvensi Putu Wijaya: Sebuah Tinjauan Selintas" dalam Horison No. 4, XXI, April 1984.

1994. Pengantar Sosiologi Sastra. Yogyakarta: Pustaka Pelajar.

Goldmann, Lucien. 1981. Method in Sociology of Literature. Oxford: Basil Blackwill Publisher.

Harymawan, RMA. 1993. Dramaturgi. Bandung: PT Remaja Rosda Karya.

Jassin, H.B. 1985. Tifa Penyair dan Daerahnya. Jakarta: Gunung Agung.

Lubis, Mochtar. 1981. Teknik Mengarang. Jakarta: Nunang Jaya.

Mohammad, Goenawan. 1981. Seks, Sastra, Kita. Jakarta: Sinar Harapan.

Oemarjati, Sri Boen. 1971. Bentuk Lakon dalam Sastra Indonesia. Jakarta: Gunung Agung.

Pradopo, Rachmat Djoko. 1976. Prosa Kesusasteraan Indonesia Sebelum Perang Dunia II. Yogyakarta: Laporan Penelitian Fak. Sastra UGM, Proyek PPPT-UGM 1976. No. 81.

Rendra. 1973. "Mastodon dan Burung Kondor". Manuskrip. Yogyakarta: Bengkel Teater. 1975. "Kisah Perjuangan Suku Naga". Manuskrip. Yogyakarta: Bengkel Teater. 1988. Panembahan Reso. Jakarta: Pustaka Kita.

Rendra. 1983. Mempertimbangkan Tradisi. Jakarta: Gramedia.

Sahid, Nur. 2004. Semiotika Teater. Yogyakarta: Lembaga Penelitian ISI Press. 2008. Sosiologi Teater. Yogyakarta: Penerbit Pratista. 1988. Memahami Cerita Rekaan. Jakarta: Pustaka Jaya.

Stanton, Robert. 1965. An Introduction to Fiction. New York: Holt Rinehart

Waluyo, Herman J. 2007. Drama, Naskah, Pementasan dan Pengajarannya. Surakarta: Kerjasama Lembaga Penelitin Pendidikan dan UPT Penerbitan dan Percetakan UNS Press. Universitas Sebelas Maret Surakarta.

Wellek, Rene \& Austin Warren. 1989. Teori Kesusasteraan. Jakarta: Gramedia. 